\title{
Impact of Demonetisation on Indian Stock Market: With Special Reference to Sectoral Indices in National Stock Exchange of India
}

\author{
Dr.P.Chellasamy, Anu.K.M \\ ${ }^{I}$ Faculty, School of Commerce, Bharathiar University, Coimbatore-641046. Tamil Nadu, India. \\ ${ }^{2}$ PhD Research Scholar, School of Commerce, Bharathiar University, Coimbatore-641046. Tamil Nadu, India.
}

\begin{abstract}
The study focussed on the impact of demonetisation on the Indian stock market. The role of cash transactions in an informal economy is critical. With 86 percent of the monetary base being washed off, economic activity in the short run is likely to be adversely impacted. Study revealed that Public sector banking segment, Pharma, Energy and IT has recorded a rise in returns after the announcement of demonetisation. The study concluded that the there is a wide spread negative returns across sectors after demonetisation which reflects the immediate negative sentiments attached with the overall economic activity.
\end{abstract}

Keywords: Demonetisation, NSE, India.

JEL Classification code: C10, E44

\section{Introduction}

The Government of India on 8 November 2016 enacted a policy to demonetise ₹500 and ₹1,000 banknotes. The government claimed that the demonetisation was an effort to stop counterfeiting of the current banknotes allegedly used for funding terrorism, as well as a crack down on black money in the country. The move was described as an effort to reduce corruption, the use of drugs, and smuggling ${ }^{1}$.Demonetization is the act of stripping a currency unit of its status as legal tender and is necessary whenever there is a change of national currency ${ }^{2}$.

\section{Demonetisation at a glance}

The sudden move to demonetise Rs 500 and Rs 1,000 currency notes is not new. Rs 1,000 and higher denomination notes were first demonetised in January 1946 and again in 1978. The highest denomination note ever printed by the Reserve Bank of India was the Rs 10,000 note in 1938 and again in 1954. But these notes were demonetised in January 1946 and again in January 1978, according to RBI data. Rs 1,000 and Rs 10,000 bank notes were in circulation prior to January 1946. Higher denomination banknotes of Rs 1,000, Rs 5,000 and Rs 10,000 were reintroduced in 1954 and all of them were demonetised in January 1978. The move was enacted under the High Denomination Bank Note (Demonetisation) Act, 1978. It was termed as "an Act to provide in the public interest for the demonetisation of certain high denomination bank notes and for matters connected therewith or incidental thereto." The Rs 1,000 note made a comeback in November 2000. Rs 500 note came into circulation in October 1987. The move was then justified as attempt to contain the volume of banknotes in circulation due to inflation. However, in the days following the demonetisation, banks and ATMs across the country faced severe cash shortages. The cash shortages had detrimental effects on a number of small businesses, agriculture, and transportation, while people seeking to exchange their notes had lengthy waits, and several deaths were linked to the rush to exchange cash but 36 years before during the situation of demonetisation, higher value notes were almost impossible to possess by the common man given the value of these amounts then.

It has been a choppy ride for the Indian equity markets that had been hit by the demonetisation and the surprise victory of Donald Trump in the US Presidential elections, exactly a month ago on November 8. India's Nifty (down 3.5\%) was the second worst performing index in Asia after Philippines, and the fourth globally after Mexico (down 5.9\%), Brazil (4.3\%) and Philippines (down 3.9\%). The frontline benchmark indices - S\&P BSE Sensex and the Nifty50 - that lost around $7.5 \%$ during the month, though have managed to recoup some losses. The Nifty50 index, for instance, hit an intra-day low of 7,916 levels on November 21 has clawed back to 8,200 levels by December 08 .

\section{Research Issue}

The announcement of demonetization of Rs 500 \& 1000 notes by the Prime Minister of India has lead to a shortterm pain. This is evidenced by long queues in front of banks, cashless ATMs and reduced small trade market

\footnotetext{
${ }^{1}$ India Today. 8 November 2016

${ }^{2}$ Reserve Bank of India. 8 November 2016.
} 
Impact of Demonetisation on Indian Stock Market: With Special Reference to Sectoral Indices in ..

activities bear testimony to it. A reliable criterion to gauge the immediate economic impact of a sudden policy shock is to observe stock market trends. Traditionally viewed as a predictor of the economy, sharp and persistent plunges in stock market indices could indicate deterioration in economic activity. These demonetization measures have had significant and immediate impact on the state of the Indian economy. These measures are also expected to result in long-term impact on certain industries and sectors. Hence the researcher have framed the following research question

$>$ What is the Impact of Demonetisation on Sectoral Indices in National Stock Exchange (NSE)?

\section{Methodology}

The aim of the research was to investigate the impact of demonetisation on Nifty Sectoral indices. The study used closing index for the period from October 3rd to December 92016 which contain 47 observations. To study the impact of demonetisation, the study period is divided into pre and post demonetisation period. 25 trading days before the event (October 3-November 8) with a period of 22 trading days after the event (November 9-December 9) and all data are obtained from NSE website. Ordinary least square was utilised for the study.

\section{Results \& Discussion}

The price movement of Nifty Sectoral indices for the pre and post demonetisation has been presented in the chart 1.

Chart 1: Price movement of Major Sectoral Indices at NSE

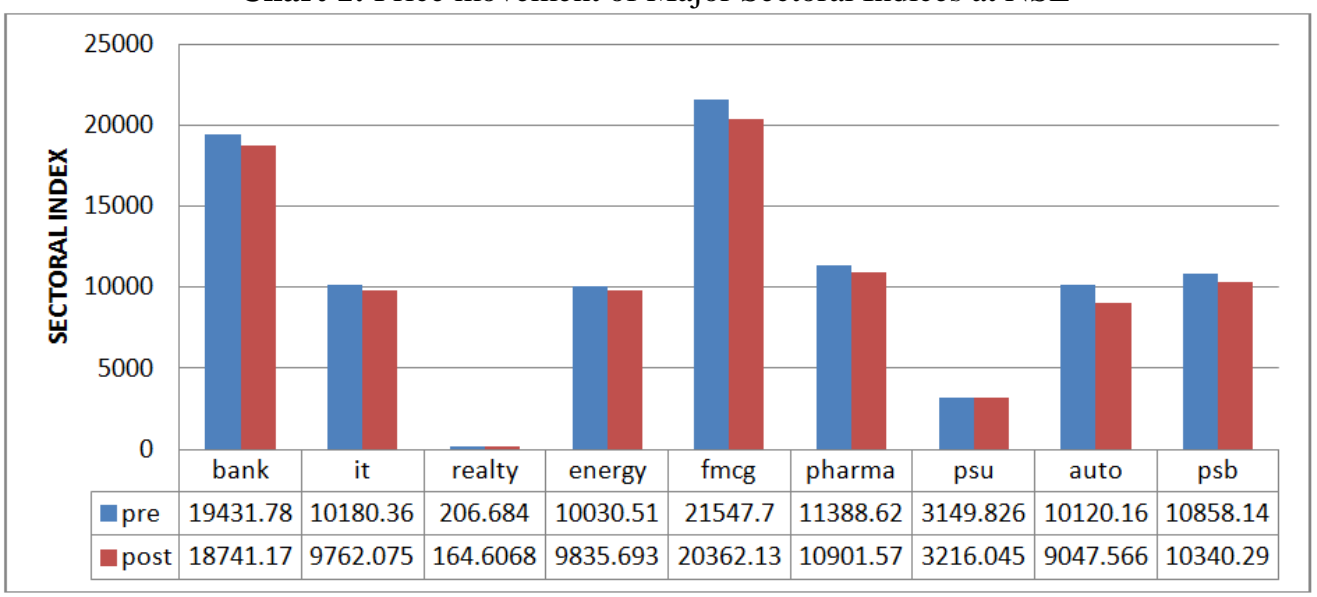

Source: nseindia.com

Chart explains the average indices in NSE before and after the announcement of Government of India's decision to cancel the legal tender character of ₹500 and ₹1,000 banknotes with effect from 9 November 2016. From the table it can be inferred that among the sectoral indices, realty, auto, private bank and fast moving consumer goods (FMCG) were the worst hit on the National Stock Exchange (NSE), On the other hand PSU bank gained during the period.

\section{Least Square Regression Analysis}

To assess the impact of demonetisation on sectoral returns in NSE, a Dummy variable representing the pre and post period has been included as explanatory variable and the results has been presented in the following tables.

\section{CNX AUTO}

Table 1: Least Square Regression result for Auto Returns

\begin{tabular}{|c|c|c|c|c|}
\hline Variable & Coefficient & Std Error & t-statistic & Prob. \\
\hline C & -0.075 & 0.328 & -0.230 & 0.819 \\
\hline Demonetisation & -0.292 & 0.474 & -0.614 & 0.542 \\
\hline
\end{tabular}

Coefficients: $\beta 0=-0.075, \beta 1=-0.292$

From the table 1 it can be inferred that the expected average return of Auto sector before demonetisation period is -0.075 and the expected average return after demonetisation is $-0.367(-0.075+-0.292)$. It indicates that the average return in automobile sector has decreased by 0.292 that is by 29.2 percent. More importantly, all purchases, except two-wheelers, have mandated PAN card disclosure in the automobile industry. This had allowed cash transactions for buying two wheelers. With demonetisation, a reduction in cash 
transactions has restrained the demand for two-wheelers and has had a short run adverse impact on the industry. Secondly, luxury car segments have been a safe haven for spending unaccounted money. With demonetisation and massive withdrawal of money in circulation, the sector is likely to have a significant impact, with the resultant impact being seen in the index.

\section{CNX BANK}

Table 2: Least Square Regression result for Bank Returns

\begin{tabular}{|c|c|l|l|}
\hline Variable & Coefficient(Bank Nifty) & Coefficient (PSU) & Coefficient (PrvtSB) \\
\hline C & -0.014 & -0.138 & 0.018 \\
\hline Demonetisation & -0.166 & 0.405 & -0.282 \\
\hline
\end{tabular}

Table explains the impact of demonetisation on Banking sector returns. From the table $\mathrm{C}$ indicates the expected average returns of Banking Sector before demonetisation and the value is -0.014 . The coefficient value -0.166 reveals the difference in returns during pre and post demonetisation. It can also be inferred from the result that the average return for the post demonetisation is $-0.18(-0.014+-0.166)$.

Despite the wide uncertainty on the effects of demonetisation in the economy, the banking sector has been positively affected. With a rise in deposits both for current and savings accounts and falling interest rates, demonetisation is expected to spur liquidity and treasury gains. However, table indicates that the average post demonetisation returns for the banking sector is $0.16 \%$ less than the return before demonetisation. This requires segregating the sector into the public and private segments.

The result also shows that the public banking sector recorded a higher average return of 0.40 percent post demonetisation. This rise could be attributed to the fact that public banks have a major share (approximately 80\% as of March 2016) in Jan Dhan Yojna accounts. With the old Rs 500 and Rs 1000 notes becoming invalid, these accounts and hence the public sector banks may witness a huge inflow of deposits. The private banking sector, in contrast, witnessed negative impact, a drop of 0.28 percent due to demonetisation. One possible reason may be that due to the intertwined structure of various sectors with banking

One of the reasons for the opposite effect across the two banking segments may be due to the base effect for public banks since the profitability of public banks is one-fourth of the private banks. To summarise, although public sector banks have reflected positive returns post demonetisation, the effect is not strong enough to offset the negative impact on the private banking sector.

Table 3: Least Square Regression result for IT Returns

\begin{tabular}{|c|c|c|c|c|}
\hline Variable & Coefficient & Std Error & t-statistic & Prob. \\
\hline C & -0.119 & 0.256 & -0.466 & 0.642 \\
\hline Demonetisation & 0.126 & 0.371 & 0.3409 & 0.735 \\
\hline
\end{tabular}

The impact of demonetisation on IT sector returns is presented in Table . coefficient of $\mathrm{C}$ indicates that the average returns during pre demonetisation period is -11.9 percent. From the result it can also be inferred that the average return after the demonetisation has been announced is $0.007(-0.119+0.126)$. Demonetization probably impacts the least on stocks in this sector since they gets most revenue in Forex and get everything via banking channels ${ }^{3}$.

Table 4: Least Square Regression result for Realty Returns

\begin{tabular}{|c|c|c|c|c|}
\hline Variable & Coefficient & Std Error & t-statistic & Prob. \\
\hline C & -0.21 & 0.526 & -0.403 & 0.689 \\
\hline Demonetisation & -0.43 & 0.76 & -0.568 & 0.572 \\
\hline
\end{tabular}

The mean return of realty sector post demonetisation is $0.43 \%$ lower than pre demonetisation period. Kalmesh Rao, CEO, Kotak Securities is in the opinion that realty stocks as the sector will be among the worst affected by the demonetisation move ${ }^{4}$. According to the study of Ritika Jain, it is revealed that Property is another dominant route for storing black money. This coupled with a multilayered tax system (Stamp duty and registration charges, VAT and Service Tax), the sale price of properties is generally higher than the documented price. Besides, the incidence of property undervaluation is very high in secondary markets. Demonetisation may navigate this sector to a more organised system. However, the short-term reduced volumes in resale market and reduced demand has put downward pressure on land prices.

\footnotetext{
${ }^{3}$ Rajat Sharma, "Demonetization: Impact on stock markets"

${ }^{4}$ Narendra Nathan, "How demonetisation and Donald Trump's victory impact your investments"
} 
Impact of Demonetisation on Indian Stock Market: With Special Reference to Sectoral Indices in ..

\section{CNX ENERGY}

Table 5: Least Square Regression result for Energy Returns

\begin{tabular}{|c|c|c|c|c|}
\hline Variable & Coefficient & Std Error & t-statistic & Prob. \\
\hline C & -0.034 & 0.202 & -0.170 & 0.865 \\
\hline Demonetisation & 0.171 & 0.292 & 0.584 & 0.562 \\
\hline
\end{tabular}

Table 5 presents the impact of demonetisation on Nifty Energy Index. The result discloses that the average return during the pre demonetisation period is -0.034 percent where as the average return post demonetisation is 0.137 percent. It can be concluded from the result that the post demonetisation return has increases by 0.17 percent.

\section{CNX FMCG}

Table 6: Least Square Regression result for FMCG Returns

\begin{tabular}{|c|c|c|c|c|}
\hline Variable & Coefficient & Std Error & t-statistic & Prob. \\
\hline C & 0.035 & 0.230 & 0.155 & 0.877 \\
\hline Demonetisation & -0.299 & 0.333 & -0.897 & 0.374 \\
\hline
\end{tabular}

Table 6 indicates that a subset of Nifty India Consumption Index, FMCG (Fast moving consumer goods) witnessed a decline of $0.29 \%$ after demonetisation. According to the report, it is revealed that the sudden drop in money supply and increased incidence of deposits have had an adverse effect on consumption in the economy. This sudden demand reduction further leads to a multiplier effect due to decline in consumer confidence. With consumers preferring to hold cash in hand, consumers will stick to purchasing necessities and postpone/cancel buying premium FMCG products. Similarly, producers will curb production in order to avoid stock pile up.

\section{CNX PHARMA}

Table 7: Least Square Regression result for Pharma Returns

\begin{tabular}{|c|c|c|c|c|}
\hline Variable & Coefficient & Std Error & t-statistic & Prob. \\
\hline C & -0.353 & 0.279 & -1.263 & 0.213 \\
\hline Demonetisation & 0.473 & 0.404 & 1.169 & 0.248 \\
\hline
\end{tabular}

It is revealed from the table 7 that the mean return of Pharma sector post demonetisation has increased by 0.47 percent. As cash flow is diminishing, all the transactions will be carried on through banks and online. There will be accurate profit earning report at all steps. No one can take much profit as he has to show it in his income tax return ${ }^{5}$.

\section{Conclusion}

The purpose of the study was to determine the impact of Demonetisation on Stock Market of India. Result from the Ordinary Least Square support that demonetisation or withdrawal of higher denomination currency has a significant impact on the Stock market for the Indian economy. The result reveals that average returns on most sectors have exhibited negative values. Public sector banking segment, Pharma, Energy and IT has recorded a rise in returns.

The role of cash transactions in an informal economy is critical. With 86 percent of the monetary base being washed off, economic activity in the short run is likely to be adversely impacted. The wide spread negative returns across sectors after demonetisation reflect the immediate negative sentiments attached with the overall economic activity. However, with Jean Dréze calling demonetisation a big gamble for India, the possibility of a favourable outcome cannot be ruled out. The possibility of these effects being temporary may seem to be a ray of hope.

\section{References}

[1]. Joel Rebello \& Gayatri Nayak, (Nov 29, 2016) Demonetisation and its side-effects, The Economic Times,Retreivedfrom http://economictimes.indiatimes.com/articleshow/55678393.cms?utm_source=contentofinterest\&utm_medium=text\&utm_campaig $\mathrm{n}=\mathrm{cppst}$

[2]. Narendra Nathan (November 14 2016),How demonetisation and Donald Trump's victory impact your investments, The Economic Times, Retreived from http://economictimes.indiatimes.com/articleshow/55384579.cms?utm_source=contentofinterest\&utm_ medium=text\&utm_campaign=cppst

[3]. Pronab Sen, (16/11/2016) Modi's Demonetisation Move May Have Permanently Damaged India's Informal Sector

\begin{tabular}{l}
${ }^{5}$ Pharma Franchise Help \\
\hline DOI: $10.9790 / 5933-0803015154$ \\
www.iosrjournals.org
\end{tabular}

